\title{
Policy Advocacy Training for Women Victims of Violence in Maros Regency
}

\author{
Muh. Tang Abdullah*, Andi Ahmad Yani, Atta Irene Allorante, Amril Hans \\ Public Administration Study Program, Faculty of Social and Political Sciences, \\ Universitas Hasanuddin, Makassar, Indonesia
}

Submitted: August 05 ${ }^{\text {th }}$ 2018; Revised: November 23 ${ }^{\text {rd }} 2020$; Accepted: December $07^{\text {th }} 2020$

\begin{abstract}
Keywords: policy advocacy local regulations protection of women
\end{abstract}

Abstract Cases of violence against women in Maros Regency are quite high. For example, in 2016, according to Department of Women Empowerment and Child Protection (DP3A) data, there were 68 cases and 21 police data cases. Likewise, divorce data in the Religious Courts are more caused by domestic violence. Of course, this social problem must be immediately addressed through local government policies. However, in fact, no policy specifically regulates the handling of this problem. Therefore, community service in the form of policy advocacy training for village women victims of violence needs to be carried out. This advocacy training was attended by 25 participants from various villages. Participants were provided with policy advocacy materials covering (1) government policies and programs on the protection of women; (2) the concept and practice of policy advocacy; (3) issues of violence and protection of women; (4) technical public speaking and lobby strategy, and (5) public opinion and press release materials. The results of the training evaluation resulted in an increase in knowledge and skills for participants after following the entire set of materials provided. Recommendations for activities are suggested to immediately take more concrete action in the form of policy advocacy to encourage the issuance of the Regional Regulation (Perda) of Maros Regency concerning Protection of Women from Violence.

\section{INTRODUCTION}

This community service activity was carried out in Maros Regency. This community service focused on policy advocacy related to the protection of women who are victims of various types of violence. For this reason, in this part of the situation analysis, the locus of service will be described empirically about the existing situation according to data on violence against women in recent years. These conditions and data are presented in both qualitative and statistical form from various sources.

Behind all the natural beauty and cultural wisdom of Maros Regency, it turns out that various griefs are stored in the eyes of women in this area. The data collected from the Office of Women's Empowerment and Child Protection (DP3A) in 2016 contained 68 cases of violence against women, while data from the police and social workers obtained 21 cases of various forms of violence (Table 1 ). Another fact was revealed from the cases that were successfully compiled by the DP3A of Maros Regency because it turned out that out of 68 cases, 40 of them were cases of Domestic Violence (KDRT), which were also revealed because of reports from victims.

ISSN 2460-9447 (print), ISSN 2541-5883 (online)

*Corresponding author: Muh. Tang Abdullah

Public Administration Study Program, Faculty of Social and Political Sciences, Universitas Hasanuddin, Jl. Perintis Kemerdekaan Km.10, Tamalanrea, Makassar, 90245, Indonesia

Email: muhtangabdullah@yahoo.co.id 
Table 1. Data on violence against women in Maros Regency 2017 (Maupe Maros Document, 2017)

\begin{tabular}{cccc}
\hline Sources & $\begin{array}{c}\text { Domestic } \\
\text { violence } \\
\text { (KDRT) }\end{array}$ & Others & Amount \\
\hline DP3A & 40 & 28 & 68 \\
Polres/ & - & 21 & 21 \\
Social & & 49 & 89 \\
Amount & 40 & & \\
\hline
\end{tabular}

Violence against women can occur anywhere, but one of the most vulnerable places is households that usually end up in the Religious Courts. The Maros District Religious Court itself recorded that there were approximately 900 cases that entered in 2017 and 471 of them were divorce cases, from these data 337 were cases of divorce (the wife's initiative), the rest were cerai talak (husband's initiative), this reflects the question: why are more women filing for divorce, meaning that there has been "dissatisfaction", "discomfort" and even "insecurity" experienced by the wives who filed it. Likewise, with jobs, $25 \%$ are housewives, $22 \%$ do not work, $14 \%$ are civil servants, the rest are other jobs.

Home is a place to return to, a place of refuge from all dangerous violence but it turns out that this is inversely proportional to the facts from the data where the incidents of violence against women occurred, where $62 \%$ of them occurred at home, $7 \%$ outside the home, $5 \%$ at school, $2 \%$ at work and $24 \%$ in other places.

Although the data does not describe the condition of Maros Regency as a whole, because it is only obtained from those who report but it requires joint attention, especially the related SKPDs such as the DP3A Women's Empowerment and Child Protection Agency that handle this problem are relatively new and of course have limited resources compared to other agencies.

In the perspective of gender-based violence, WHO (2009) provides a definition:

"Violence involving men and women, in which the female is usually the victim; and which is derived from unequal power relationships between men and women. Violence is directed specifically against a woman because she is a woman, or affects women disproportionately. It includes, but is not limited to, physical, sexual and psychological harm (including intimidation, suffering, coercion, and/or deprivation of liberty within the family, or within the general community)".

It means that violence involves men and women, where women are always victims of injustice. Violence is not only limited to physical, sexual, psychological but all intimidation, suffering, coercion, and deprivation of liberty in the family and or community in general.

The causes of violence against women can be caused by many factors, not only with a structural dimension but also a cultural dimension. According to Amalia (2011), the factors that cause violence against women generally include: (1) the development of a culture that does not respect ethics; (2) lifestyle and promiscuity between men and women; (3) lack of appreciation and practice of religious norms; (4) low level of community control; (5) court decisions deemed unfair; (6) the perpetrator's inability to control his emotions and sexual desires; and (7) desire for revenge by the perpetrator.

In addition, socio-culturally the occurrence of acts of violence in the household is due to customs that tend to favour men so that women must submit to men, because men (husbands) are seen as the owners of power. Husbands are breadwinners and fulfil their needs, so they feel more entitled to their wives and children. But the bottom line is a lack of faith and awareness of peace and love.

In understanding policy advocacy, according to Nugroho (2014) and Topatimasang (2000), it is better to first understand that the policy is a legal system (system of law) which includes: (1) content of law, namely a description or elaboration written from a policy set out in the form of laws, regulations and government decrees; (2) legal administration (structure of law), namely all institutional and implementing instruments of the content of the applicable law (legal institutions and their implementing apparatus); and (3) culture of law; namely perception, understanding, acceptance, implementation practices, interpretation of two aspects of the legal system above the content and management of the law. Thus, Topatimasang (2000) continued, concluded that a good policy advocacy program is one that is deliberately and systematically designed to push for changes in the content, management and the prevailing legal culture.

Regarding the handling of violence against women, the state has issued various policies and legal regulations to protect victims and prevent domestic violence, such as (1) Article 28G of the 1945 Constitution; (2) Law Number 9 of 1999 concerning Human Rights; (3) Law Number 7 of 1984 concerning Ratification of the Convention on the Elimination of All Forms of Discrimination against Women; (4) Law Number 1 of 1974 concerning Marriage; (5) Criminal Code; (6) Criminal Procedure Code; and (7) Law No. 23 of 2004 on the Elimination of Domestic Violence. According to Harkrisnowo in Amalia (2011) that the law functions and seeks to handle and punish perpetrators or lawbreakers, prevent all forms of violence, and protect victims of violence against 
women and children that continue to occur in society, especially those that occur in the household sphere.

From the perspective of empowerment, handling cases of violence against women through advocacy activities is part of the community empowerment movement strategy. As stated by Suradi (2011) and Darmawan et al. (2019) that advocacy, both policy and social advocacy, is one of the activities and strategies needed in community empowerment practices. Meanwhile, according to Suharto (2005), advocacy is a process of influencing actors in formulating public policy and can also take the form of a set of political actions by citizens who are organized to achieve certain policies.

According to Chilmiati (2014), efforts to deal with violence against women and children are continuously carried out by both formal institutions (government) and informal institutions such as non-government organizations (NGOs) and other community organizations. However, there is something that becomes a problem, namely the existence of a gap between the provisions stipulated in law and the reality that occurs in society. Chilmiati (2014) continued that the obstacles in the law enforcement process of violence against women and children was caused by two factors, namely the absence of public reports (unreported cases) which would hinder the effectiveness of the law enforcement process and if the community reports did not get a complete (unsolved) resolution from law enforcement officers will cause public distrust of the law enforcement process.

Basically, there has been a policy in the form of Regional Head Decrees Number: 1063 / KPTS / 300 / VII / 2014 concerning the Establishment of a Committee on the Socialization of the Prevention of Violence Against Women and Children in Maros Regency and has been implemented in the form of extension activities that present related speakers. However, it seems that this policy has not been effective in dealing with various problems related to protecting women from violent behavior. This is evidenced by the phenomenon described in the previous situation analysis section. This shows that in Maros District, in the last few years there have been cases of violence against women in various characteristics and forms. This description is of course a rational consideration and reason for the importance of a stronger policy/regulation than just a regional head decision.

The policy that could be more effective is the issuance of a regional regulation (Perda) of Maros Regency which functions to regulate government affairs regarding the protection of women. In order for this regional regulation to be realized immediately, it is deemed necessary for the emergence of participation from various elements of society such as social organizations and NGOs, especially those who have been factually focused and concerned about the existence of marginalized women. It is hoped that their participation can be a driving force so that an agenda for the formation of regional regulations which aims to regulate how to protect women from acts of violence and injustice is expected.

Based on the description above, it is important that policy advocacy is carried out for women victims of violence, so one of the efforts to encourage policy advocacy is through policy advocacy training for these vulnerable groups of women. Therefore, this solution offer is a concern of the community service program implemented by the Hasanuddin University Lecturer Team.

\section{METHOD}

The strategy for this service activity is carried out through collaboration between the Unhas Research and Community Service Institute (LP2M), the Maros Regency Women Empowerment and Child Protection Service (DP3A) and the Maupe Women's Political School (SPPM) Maros. This community service was designed in the form of training, namely policy advocacy training for village women's groups in Maros Regency (Figure 1). The aim of this training was to increase the capacity in the form of knowledge and skills in policy advocacy, especially those related to the issue of protecting women from acts of violence.

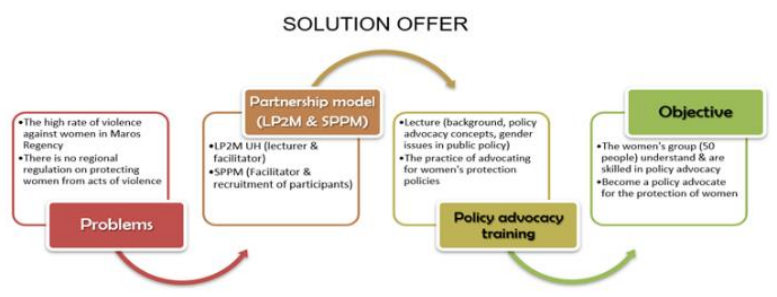

Figure 1. Policy advocacy training flow strategy for women's groups

Basically, this policy advocacy training applies two types of training methods that have been known so far. These two training methods were introduced by Bernardin and Russel (2013). Types of training methods include: (1) Informational methods, namely methods that use one-way communication, through information conveyed by the trainer or instructor to the training participants. This method is used to teach factual things, certain skills and/or attitudes. The techniques used are usually lectures with presentation, audio-visual and self-direct learning. (2) Experiential methods, namely methods that promote more flexible and dynamic communication, for both coaches and participants, and directly using the tools provided. This second method is usually applied to teach knowledge and skills and abilities, both software and hardware. 
This second training method is more facilitative and participant-oriented. So, this policy advocacy training for women victims of violence applies a combination of informational and experiential methods simultaneously.

This advocacy training was carried out over two days, namely on 19-20 July 2018 at the RM Nusantara Turikale Hall, Maros Regency. The training participants consisted of a group of 25 women. The women's group that participates in this advocacy training is a group of village women who have long been assisted by SPPM Maros.
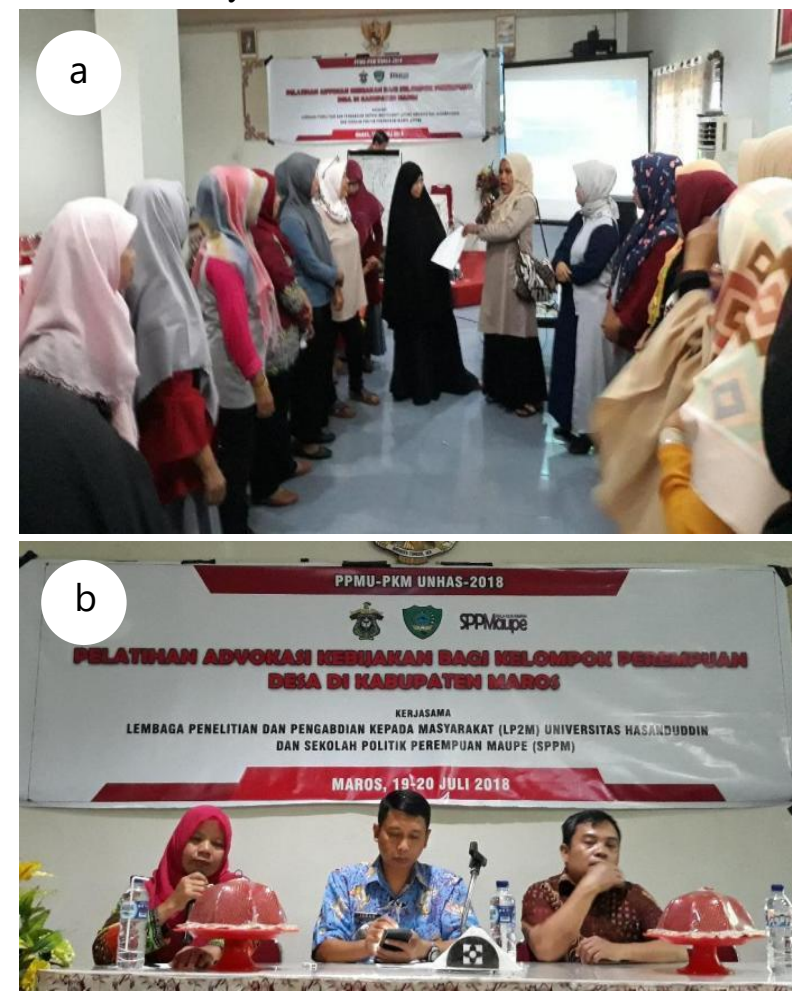

Figure 2. Activities of policy advocacy training: (a) Brainstorming of issues of women's violence; (b) Delivery of the topic policies and programs of policy advocation

The presentation of the training material is divided into two parts, namely (1) the first day of material containing knowledge covering: Maros Regency government policies and programs on women's protection, policy advocacy concepts and practices, issues of violence and women's protection; (2) on the second day, the material is tutorial on how to do technical public speaking and strategy on lobbying, as well as public opinion and press release materials.

All training materials were delivered by resource persons from the Hasanuddin University Faculty of Social and Political Science Service Team which consisted of four lecturers and three students. Primary data was obtained through interviews and observations and secondary data was obtained through tracing official local government documents such as policies and programs that have been implemented so far. The interview process was conducted with the head of the DP3A Maros Regency informant who was present as a resource person and one informant from an NGO.
To determine the effectiveness of the training, an evaluation is carried out which is reflected in the form of a pre-test and a post-test of the participants at the beginning and end of the training. Evaluation of training participants is carried out by first determining indicators of measuring the capacity of participants knowledge of the material presented. Indicators for measuring the capacity of knowledge start from knowing, quite knowing and do not knowing. The data collection technique for participants' knowledge capacity indicators was carried out through distributing questionnaires to participants accompanied by a facilitator.

\section{RESULT AND DISCUSSION}

This discussion began by presenting statistical data on the condition of Maros Regency, both geographically, demographically, and in government administration. Sociologically, the people of Maros Regency are strongly influenced by 2 (two) main ethnic groups of the people of South Sulawesi, namely Bugis and Makassar tribes. The Bugis and Makassar ethnic communities are the majority, apart from other ethnicities such as Toraja, Javanese and Chinese.

According to BPS Maros in Figures (2018), in 2018 Maros Regency became a residence for around 342,890 people. This figure consists of 167,724 male and 175,166 females. The sex ratio of the population of Maros Regency in 2018 was 95.75. This value indicates that the population of women is more than that of men, with a ratio of 96 female residents per 100 . The average population living in Maros Regency is 210 inhabitants per $1 \mathrm{~km} 2$.

Meanwhile, Turikale District is the most densely populated sub-district. In 2018, it was recorded that around 1,463 residents lived every $1 \mathrm{~km} 2$ of the Turikale District area. The population of Maros Regency is dominated by young people, this is indicated by the shape of the population pyramid of Maros Regency which is bulging at the bottom (young age).

The dependency rate is 52.4 percent, indicating that every 100 people who are in the productive age range (15-64 years) have 53 dependents who are not yet productive (0-14 years) and are no longer productive (over 65 years). Or more simply, it can be said that 2 people of productive age bear 1 person who is not productive. The population, which amounts to 342,890 people, is spread across 14 subdistricts covering 80 villages and 23 sub-districts. There are 89 neighbourhoods' and 320 hamlets. There are 22 villages in the self-supporting category and 22 villages in the self-employment category, and 59 villages in the self-sufficiency category. When viewed from the description of the population and government area of 
Maros Regency, it can be concluded that most or more than $70 \%$ of the population live in rural areas.

In the context of this advocacy training, it can be understood that advocacy against violence against women is not the same as advocacy in general. Advocacy work in this context has a peculiarity, that is, it does not only pay attention to basic principles in general, but also needs to understand more specific principles related to specific problems experienced by women.

According to Subiyantoro (2006), he explains that the uniqueness of this advocacy is related to several aspects. Firstly, from the aspect of the perpetrator. Violence against women has very significant differences regarding the perpetrators of violence. If the violation of human rights (HAM) in general, the perpetrators are closely related to the roles of the state, then the perpetrators of violence against women are not only the state but also the community and even their immediate family such as husbands, fathers, uncles, boyfriends, neighbours' or people known to the victims. In this context, the responsibility of the state alone is not sufficient but also requires the responsibility of the community and institutions that are built in the community, such as customary, religious, and so on.

Second, violence against women knows no place. Violence can occur both in the public setting and in the family setting. If it is mapped, violence against women occurs in three spheres, namely family, community and state. In a number of cases, it was family areas where the violence occurred most. The consequence of this situation is how to create policies that can enter into private matters, but still respect privacy.

Thirdly, violence against women cannot be eliminated from the root of the problem, namely discrimination. In this context, advocacy can not only be directed at formal structural institutions, but also cultural institutions. Violence against women cannot be separated from the process of internalizing social values in a society that is built systematically, either through public policies, local culture or religious teachings which are interpreted in a gender-biased manner. As a result of this internalization, violence against women is considered normal by society, even if there are women who are more empowered, society tends to resist it.

Subiyantoro (2006) also provides an explanation of an important aspect that needs to be considered in the advocacy process against violence against women, namely the existence of victims. In this process, victims are the main indicator that determines whether ongoing advocacy can empower or, on the contrary, causes violence for the second time. This is important to note because in the process of fighting for the case, the victim can become more depressed and confused. For this reason, in advocacy that involves victims, service institutions must have sensitivity and understanding of the mechanism for the possibility of a repetition of violence against victims, so that as little as possible repetition of violence against victims can be avoided.

In a broader aspect, to ensure that the advocacy process does not result in repeated violence against victims, the advocacy process must also be seen as a process of empowering victims. The victim is not only positioned as a passive party, she only follows legal, medical and psychosocial remedies without understanding the importance of this effort. Advocacy should make victims as parties who have awareness of the events they are experiencing and then carry out medical, psychosocial recovery and carry out legal prosecution. Apart from being part of empowerment, an aspect that also needs to be considered in advocacy against violence against women is an understanding of the principles of victim rights. This is related to two interests that arise, both from the side of the victim and the side of the party doing advocacy. The problem lies in the different interests of each party. It is in this context that understanding the rights of victims really needs to be considered, especially for those who carry out advocacy.

In this policy advocacy training activity, the measurements of the success and effectiveness of the training have been determined. As described in the method section, in the implementation of the training an evaluation of the participant's knowledge capacity was carried out on the first day before the material was delivered, which was called a pre-test. Then on the second day to evaluate the level of progress of the participants' knowledge capacity, a post-test was carried out which aims to measure the development of the participants' knowledge capacity after following all the material presented by the resource persons and facilitators.

Table 2 below, shows that the main objective of this policy advocacy training is to increase participants' understanding and knowledge of the various training materials presented. As shown in the table, that of the 25 participants on the indicator knowing the material, only an average of $17.6 \%$ was not presented at the time. Then it increased to an average of $76.6 \%$ of the participants who already understood and knew materials related to policy advocacy. This also means that participants who initially knew enough and did not know the advocacy materials experienced a significant decline. Thus, it can be concluded that the results of measuring the effectiveness of training have been very successful in achieving their objectives. 


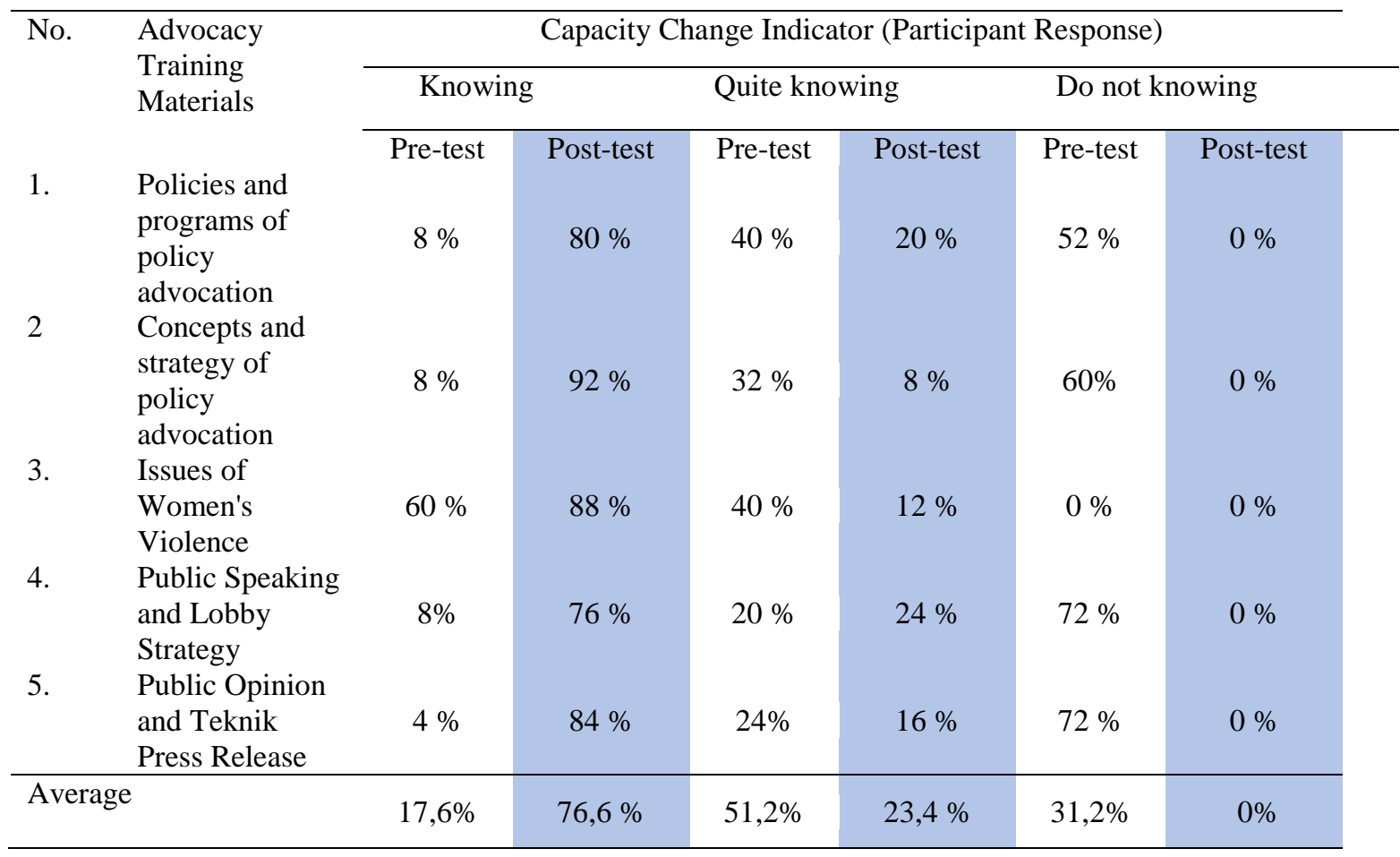

Note: Processed from the training participant evaluation questionnaire form data, 2018

The effectiveness of the training is also influenced by several factors, both supporting and inhibiting factors. The training support factor found in this dedication was the high enthusiasm and expectations of the participants to participate in the activity. So that this interest can make it easier for the speakers to develop the advocacy capacity of each participant

In addition, it is also known that there are inhibiting factors that need to be anticipated when carrying out similar activities in the future. The inhibiting factor is that more technical material cannot be implemented, such as in the form of tutorials for participants. This is important because a more technical tutorial activity can basically improve the practical skills that groups should have in advocating for local policies or regulations.

\section{CONCLUSION}

The high rate of violence against women and the absence of effective policies (regional regulations) in Maros Regency is the basis for the importance of carrying out policy advocacy activities. This policy advocacy is intended to encourage the issuance of policies in the form of Regional Regulations (Perda) of Maros Regency which regulate the protection of women from acts of violence. This policy advocacy must be carried out in a participatory manner by involving stakeholders' especially women's groups as objects of violent acts. Community service in the form of policy advocacy training is intended to increase the capacity to advocate for a policy. The point is, of course, that regional regulations are issued immediately which are expected to be an effective solution in overcoming the problem of widespread violent behaviour against women in Maros Regency.

\section{ACKNOWLEDGMENT}

We would like to thank the Chairperson of LP2M UNHAS for the Community Service Program UNHASCommunity Partnership Program (PPMU-PKM). We also thank the DP3A Maros Regency, SPPM and the student team: Risal Fauzi, Riswanto RM, M. Irvan Nur Iva, Novayanti S. Rukmana, and Muh. Pudail.

\section{REFERENCE}

Amalia, Mia. (2011). "Kekerasan Perempuan Dalam Perspektif Hukum dan Sosiokultural". Jurnal Wawasan Hukum, 25(2), 399-411 DOI: $10.25072 /$ jwy.v25i2.25

https://www.researchgate.net/publication/31999 7751

Badan Pusat Statistik Kabupaten Maros. (2018). Maros Dalam Angka 2018. http://maroskab.bps.go.id

Bernardin H. John, and Joyce E. A Russell. (2013). Human Resource Management: An Experiential Approach. London: McGraw-Hill Medical Pub.

Chilmiati, Fika dan RB. Sularto. (2014). "Kebijakan Advokasi Terhadap Perempuan dan Anak Berbasis Perlindungan Korban Kekerasan”. Law Reform, 9(2), 111-121. https://ejournal.undip.ac.id/index.php/lawrefor $\mathrm{m} /$ article/view/12449/9398.

Darmawan, Widya, Eva Nuriyah Hidayat, dan Santoso T Raharjo. (2019). “Advokasi Sosial Terhadap 
Anak Korban Kekerasan Seksual: Kajian Pustaka." Prosiding Penelitian \& Pengabdian Kepada Masyarakat. 6(1), 96-107. http://jurnal.unpad.ac.id/prosiding/article/downl $\mathrm{oad} / 22822 / \mathrm{pdf}$

Nugroho, Riant. (2014). Public Policy; Dinamika Kebijakan Publik, Analisis Kebijakan Publik dan Manajemen Politik Kebijakan Publik. Jakarta: PT. Alex Media Komputindo.

Nurharyati, Wahyu, A. Nelson Aritonang, dan Aribowo. (2017). "Advokasi Program Pemberdayaan Perempuan Keluarga Miskin Di Kabupaten Bandung”. PEKSOS: Jurnal Ilmiah Pekerjaan Sosial, 16(2), 302-324. http://journal.stks.ac.id/index.php/peksos/article /view/114/93

Pemerintah Republik Indonesia. (2014). UndangUndang Nomor 23 Tahun 2014 Tentang Pemerintahan Daerah. Jakarta

Subiyantoro, Eko Bambang. (2006). Advokasi Anti Kekerasan Terhadap Perempuan;Pengalaman Forum Belajar Bersama Komnas Perempuan. Jakarta: Komnas Perempuan Indonesia.

Suradi. (2011). “Advokasi Sosial Dalam Pemberdayaan Fakir Miskin”. Informasi, 16(2), 87-100. https://ejournal.kemsos.go.id/index.php/Sosioin forma/article

Suharto, Edi. (2005). Analisis Kebijakan Publik: Panduan Praktis Mengkaji Masalah dan Kebijakan Sosial. Bandung: Alfabeta

Topatimasang, Roem, Fakih Mansour dan Toto Rahardjo. (2000). Merubah Kebijakan Publik, Yogyakarta: Pustaka Pelajar.

World Health Organization (WHO), 2009. Promoting Gender Equality to Prevent Violence Against Women. (Series of briefings on violence prevention: the evidence) https://www.who.int/violence_injury_preventio n/violence/gender.pdf 